This is the accepted version of the article. The final, definitive version of this paper has been published in Policy Futures in Education Vol 15, Issue 3, pp. 360 - 379. First published date: $22^{\text {nd }}$ of June 2017. DOI: 10.1177/1478210317715794

\title{
Implications for equity and diversity of increasing international student numbers in European universities: Policies and practice in four national contexts
}

Jani Haapakoski

University of Oulu, Finland

Karen Pashby

Manchester Metropolitan University, UK

\begin{abstract}
This paper examines the main rationales for and possible implications of the policy of increasing international student numbers in higher education (HE). Drawing on critical discourse analysis, we map key themes emerging from two sets of data-university strategy documents and interviews with staff-collected at eight universities in four national contexts in Europe as a part of a larger project focused on ethical internationalism in HE. In our analysis of the data, we apply social cartographic mapping to consider overlapping, competing and absent discourses related to the push to increase international student numbers by using a heuristic developed in the larger project. We found the imperative to increase international student numbers to be largely driven by economic rationales across different national contexts, reflective of a corporatization trend. Where more civic rationales are presented, these discourses are ultimately framed and mediated by neoliberalism. The findings contribute insight into the complicated discursive terrain of internationalising HE. The mapping makes visible what can be taken for granted or is left unexamined. It serves as a jumping-off point for reflection on the policy, practice and research of internationalisation in $\mathrm{HE}$, promoting the formulation of key questions around the assumed benefits and ethics of internationalisation.
\end{abstract}


Keywords: Ethics, higher education, international students, internationalisation, social cartography, student recruitment

\section{Introduction}

The European Commission (2013) states that international degree mobility of students is 'the most widespread and probably still the most powerful vehicle for internationalisation, is changing dramatically in quantity and shape, and in some cases has become a critically important source of revenue for Higher Education Institutions (HEIs) (European Commission, 2013: 4). Increasing the amount of international students is a common goal across institutional and national contexts, and it is tied to increasing funding and competing for 'the best and the brightest'. In this paper, we present a set of findings from a larger project that examined the extent to which the current rush to internationalise in higher education (HE) steps over or reinforces ethical implications, including the reproduction of global inequalities. The larger project, Ethical Internationalism in Higher Education in Times of Global Crises (EIHE), was funded by the Academy of Finland (2012-2016) and involved 22 universities in nine countries in a large-scale mixed-methods study of policy-based as well as student, faculty and staff perspectives on internationalisation. The larger project investigated the barriers and opportunities for ethical engagement with internationalisation policies in HE contexts. 
Specifically, in this paper we apply the larger project's heuristic, detailed in the methodology section, to map rationales for internationalisation in terms of general justification for and desires of internationalisation, and how diversity is conceptualized. Theoretically, this research draws on literature that points to three inter-related concerns: a) in the current climate of economic crises, democratic and social purposes of HE can be fused into economic imaginaries of internationalisation (Khoo, 2011); b) this normalized version of internationalisation can re-direct social and political values towards economic rationales that reproduce market expansionism (Rhoads and Szelényi, 2011); and c) this leads to a superficial and tokenistic approach to cultural diversity that steps over ethical questions around equity and denies the corresponding reproduction of global systems of inequities (Andreotti, 2009; Andreotti et al., 2009; Abdi and Shultz, 2008; Dower, 2003). The main contribution of this study to the field is its application of a novel heuristic based on three main discursive orientations (neoliberal, liberal, and critical) and four intersections (neoliberal-liberal, liberal-critical, neoliberal-critical, and all four). While there are plenty of examples of research regarding neoliberalism in HE in a context of internationalisation (e.g. Slaughter and Rhoades, 2004; Rizvi and Lingard, 2010; Britez \& Peters, 2010), our project attempts to find new ways of understanding the current situation through using social 
cartography to identify overlaps and contradictions. There also exists research in internationalisation that considers the ethical challenges caused by the increased focus on commercialisation in HE, and how this affects the former 'public good' role of HE (e.g. Lomer, 2014; Tolofari, 2009). In this paper, we extend these discussions by highlighting a lack of attention within claims for the public role of the university in a context of commercialization to challenging the hegemony of Western knowledge production in HEIs. We seek to attend to the power asymmetries between the Global North and South in internationalisation with significant implications for cognitive and social justice (Paraskeva, 2013).

This theoretical grounding defines a key principle of ethical internationalisation among the project partners: working to make intelligible the potential reproduction of unequal power relations that are often hidden in taken-for-granted assumptions about who benefits from higher education and internationalisation and how. In this paper, we focus our critical engagement on identifying the dominance of neoliberal rationales for encouraging internationalisation in HE and particularly for increasing international student numbers. We seek to identify what other discursive orientations are observable or possible to articulate and work with, and we consider how they intersect with the strong neoliberal orientation so as to 
conflate into or perhaps mediate the dominant corporate imaginary. We also consider how diversity is valued and engaged, or simply leveraged for market potential in this context. The heuristic enables a visual mapping of the differences within and between the main discursive orientations underpinning how internationalisation and diversity are articulated in the policy and practice of internationalisation. Further, it helps to recognize how there may be multiple and contradicting discourses operating through a common goal of diversifying student demographics. By working to make intelligible where neoliberalism is compatible with or at odds with liberal and critical orientations, we use the heuristic to articulate some potential barriers to and possibilities for ethical internationalisation.

Specifically, two main research questions guided our readings of the data consisting of universities strategic documents and interview transcripts:

(a) How is internationalisation, particularly the policy to increase student numbers, rationalized and who are the key actors and/or processes associated with this aspect of internationalisation?

(b) What value is attributed to difference and under what circumstances in relation to the push to increase international student numbers? 
This paper draws on analysis of internationalisation strategy documents and interviews with those working directly with internationalisation in eight universities across four national contexts in Europe (The United Kingdom, Ireland, Sweden and Finland). Internationalisation strategy work in each country responds to European-level policies, as well as to specific national contexts. While there are some differences, in all national contexts, the push to increase international student numbers is part of a broader approach to internationalising HE and the society. Increasing numbers is linked to the idea of a shift to a new knowledge economy that requires the teaching of 'international' skills and competencies to domestic students and involves the exporting of educational degrees and services and encouragement of international mobility inwards to address national labor shortages. Of all the countries included in the paper, UK has the longest history and the most dominant position in marketoriented internationalisation (Schatz, 2016). It should be noted that Scotland has different HE traditions and perhaps a little less market-oriented approach compared to England. However, international student recruitment and economic benefit from tuition fees are important rationales in internationalisation in Scotland as well (Kemp and Lawton, 2013). In Ireland, the economic motivations have become stronger after the financial crisis in 2008 that has led universities to realign their internationalisation activities to emphasize international student recruitment in order to compensate for the state disinvestment in HE (Khoo, 2012). Also, 
both Nordic countries have entered a new phase in internationalisation as Sweden introduced tuition fees for non-EU/EEA students in 2011 and Finland will start in the Fall of 2017. As the HE sectors in each country are in direct competition with each other for the best and brightest' students, the importance of building visibility and reputation on the institutional and national level becomes essential. The national HE sectors also compete within themselves and resources are being allocated in each country via indicators that in many cases involve aspects of internationalisation (Seeber et al., 2016). Increasing and/or maintaining international student recruitment is a consistent indicator across these national contexts.

\section{Data and Methodology}

The research drawn on in this paper is part of the wider EIHE project which sought to illuminate how wider internationalisation policies are being translated at universities. For this paper, we selected data from the European participating universities and specifically from the analysis of university-level documents relating to internationalisation and interviews with employees whose work is directly related to internationalisation. The universities included in this study are DeMontfort University (England), University of Exeter (England) and 
University of Stirling (Scotland) from the United Kingdom; National University of Ireland Galway (NUIG) from Ireland; Södertörn University and Örebro University from Sweden; and University of Oulu and University of Helsinki from Finland. The larger project included 22 universities in nine countries but in this study, we focus on the European universities specifically. Although the universities included here respond to diverse European and national level policies regarding $\mathrm{HE}$ and internationalisation, the EU still forms a somewhat coherent context for the examination as they share a strong rationale to increase international student numbers as host universities. Our intention is to identify discourses from the data for discussion purposes, not for generalisation, and we acknowledge the partiality and temporality of our analysis. The sample is purposefully limited to concentrate on identifying contradicting and overlapping ways internationalisation is operating discursively across European contexts. There is an 'ethico-political imperative' (Stein, 2017: S26) to do such a mapping given the significant growth in internationalisation in Europe. Further, as has been pointed out by Tesar (2016a), the policy context of a united EU is currently contested, and yet, there are common trends across HEIs in regards to internationalisation and a common focus on increasing international student numbers that warrants investigation. 
We looked at one or two key documents from each participating European university. These documents were either general strategic plans from which we focused on what they said about internationalisation (De Montfort University, 2011; NUIG, 2012; Örebro University, 2013; Södertörn University, 2011; University of Exeter, 2014; University of Helsinki, 2012; University of Oulu, 2012; University of Stirling, 2011) or specific international strategy documents or internationalisation reports (NUIG, 2014; Södertörn University, 2012; University of Exeter, 2013; University of Oulu, 2015). All documents were collected before the completion of the interviews, and it is possible that new documents have replaced the ones used in this study. In that sense, they represent a snap shot of the main discourses evident in 2014-2015.

The interview data consists of 15 interviews that were collected in 2014-15 and all interviewees were working, at the time of the interviews, in positions related to internationalisation as international coordinators, heads of internationalisation, or academic staff assigned to work on internationalisation. There are two interviews per university; one interviewee working on policy drafting level in internationalisation in central administration of the university, and the other in implementation and on the faculty/school level. There were two exceptions; Örebro University is represented by only one interview and in the case of 
NUI Galway, both interviewees represented faculty level staff. As the sample size is rather small and to ensure the anonymity of the interviewees, quotations from the transcripts are identified by a letter to indicate the university and a number to differentiate between the participants at that university. All interviews were conducted in English which meant that some interviewees were operating in other language than their mother tongue which did not appear to cause noticeable difficulties with the interviews. The interview questions inquired into rationales and challenges of internationalisation from the student, staff and institutional perspectives. As references were made to the university strategies, the questions were sent beforehand to enable some preparation. The interviews were mostly conducted through Skype, and although the questions were consistent in every interview, inquiries and probing questions were used to clarify and deepen responses (Wood and Kroger, 2000).

In the analysis, we drew on principles of critical discourse analysis and its premise that power relations are constructed and sustained ideologically through texts, in this case policy and strategy documents and interviews (Fairclough, 2003; Taylor, 2004). The policies on internationalisation should be seen as discursive constructs, with material effects, contributing to and being constituted by the national and global contexts (Nokkala, 2007). The interview data provides a look at how the policies are interpreted at the level of practice 
and which ideological and material effects are highlighted through the take up of various discourses. Specifically, we conducted several close readings of the documents and interview texts, identifying and categorizing the key discourses related to the research questions and then reading through the data several more times to select examples illustrating the main discourses. The first research question focused on the rationalization of internationalisation more broadly and more specifically on increasing student numbers as well as examined who are considered to be the key actors and what are the key processes associated with internationalisation. The second question considered the extent to which difference was valued and under what circumstances, again with a particular focus on the push to increase international student numbers. We coded the key discourses and their sub-discourses according to the project's heuristic. This involved identifying important words and phrases that exemplified main aspects of the heuristic that will be explained in the next section.

\section{Social cartography and a novel heuristic}

Drawing on Paulston's (1999) work on social cartography as a method of articulating comparative international education findings, we use the heuristic tool to create a map of the overlapping and distinct understandings of diversity evident in strategy documents and interview data (Andreotti et al., 2016). Connecting the theoretical framework and the key 
themes emerging from the texts, the heuristic helps us to map visually the differences within and between the main discursive orientations underpinning how internationalisation and diversity are articulated in the data. Further, it helps to recognize how there may be multiple and contradicting discourses operating through a common goal of increasing and/or maintaining and/or diversifying student numbers. It is important to note that we used the heuristic as an interpretive device to frame our analysis of the findings. We do not use it as a representational device. In this sense, the findings here are not meant to be generalizable, and we acknowledge that different researchers might map the findings in a different way. In fact, the heuristic has been used for a variety of purposes by project partners (Pashby and Andreotti, 2016). In this specific piece of research, our intention is to make intelligible the overlaps and conflations we found in the various conceptualizations of internationalisation as one way to direct conversations about research and about day to day practice in HE in the context of the rush to internationalise. The findings are thus a conversation between the discourses evident in the data and the heuristic developed by the research collaboration in the wider project. Social cartography helps us to both map what discourses are evident and to recognize which are not there but could be mapped onto the cartography. It enables an iterative analysis in that sense as well (Pashby and Andreotti, 2016). The mapping is thus both an interpretative device for analysis of the sets of data in this research and a reflexive 
tool for considering implications of overlapping and contradictory conceptualizations of internationalisation for ethical approaches to policy and practice. We also hope that mapping the conflations and paradoxes in the way we have will highlight some ethical implications to which those of us working in HEIs can respond in a variety of ways.

The heuristic organizes some key discursive configurations at play in the internationalisation of HE in contemporary times. However, the EIHE project recognizes the long history of the university and its changing role in relation to the societies in which they are rooted (see Figure 1). The project identifies four historical imaginaries of HE each of which blends and interacts with the one before and after: Scholastic, Classical, Civic, and Corporate (Andreotti et al., 2016). Furthermore, the four historical imaginaries all operate under a modern/colonial global imaginary that can be conceptualized as a contested but enduring meta-narrative that naturalizes the domination of the Global North in terms of colonial social relations and the superiority of Western ideologies and knowledge (Andreotti et al., 2016; Baker, 2012). Our heuristic focuses on the interactions between the civic and corporate imaginaries of $\mathrm{HE}$ as they tend to be most dominant globally. 


\section{Corporate imaginary of HE}

Post-state financial capitalism, state divestment in $\mathrm{HE}$ Civic imaginary of $\mathrm{HE}$

WW2/cold war, state investment in massification of $\mathrm{HE}$

Classical imaginary of $\mathrm{HE}$

European Enlightenment

Scholastic imaginary of HE

Figure 1. EIHE juxtaposed imaginaries of the university (Andreotti et al., 2016: 6, republished under Creative Commons Attribution Licence 4.0).

The heuristic is composed of two parts, the three main discursive orientations and their four interfaces. It was developed through a detailed review of scholarly literature on HE in the context of internationalisation and was also informed by project partners' own experiences with internationalisation in HE (Andreotti et al., 2016; see also Pashby and Andreotti, 2016). The neoliberal discursive orientation is focused on commodification of education, the 
entrepreneurial role of the university and branding for economic benefits. Research and education are valued in instrumentalized terms: the former as a new form of production and the latter as a set of transferrable skills and competencies. In the heuristic (Figure 2), neoliberal orientation is placed at the top of the triangle symbolizing its hegemonic position in terms of overall rationales and practices of HE across contexts. Neoliberal rationales are guiding the development of $\mathrm{HE}$ worldwide as is evident in the focus on the knowledge economy where universities are perceived to be drivers of economic growth (Fairclough and Wodak, 2008). If the neoliberal orientation is a vehicle of the corporate imaginary of HE, the liberal orientation is rooted in the civic imaginary that emphasizes education as a public good and its role in the nation-building project. Education is seen as means to personal development and good citizenship, and research should be free and objective, for it is through rigorous academic research that global problems can be solved. Whereas the neoliberal orientation is strongly reflective of the corporate imaginary and the liberal orientation of the civic imaginary, neither question nor critique the overall modern global imaginary. The third discursive orientation, critical, does respond to the fact that HE has been part and parcel of the modern project which has ultimately reproduced unequal power relations despite and, in some cases, because of its academic traditions. The critical orientation is located in the civic imaginary; however, in comparison to the liberal orientation, it supports a more radical civic 
imaginary and politicizes HE with the aim of systemic change. The critical orientation is interested not only in repositioning HE as a key civic institution that promotes social good but also in the possibility of the university supporting alternative future visions. A critical approach thus promotes social and cognitive justice through making inequalities and exploitation visible and challenging taken-for-granted norms and epistemologies. In education and research, a critical orientation supports epistemic pluralism in directing work in HEIs to reach also beyond the Western scientific paradigm through, for example, indigenous knowledge systems. The critical orientation is the least common in the literature and practice but provides a useful perspective to open discussion on HE due to its radically different approach.

Importantly, although there are politicized implications of each of these discursive orientations, we do not use the heuristic in an instrumental sense. We are not judging whether or not documents or interviews with HE employees are involved in a right or wrong approach nor are we attempting to promote one way of internationalising over another, although, our theoretical groundings and commitment to an ethical approach will necessarily highlight the possibilities of the critical approaches. Rather, we aim by our use of the heuristic to help to map some contradictions within and among discursive orientations to internationalisation in 
HE. Similarly to the larger project out of which the heuristic was created, we aim to elicit discussion and reflexivity and to contribute to making intelligible the possibilities and constraints for ethical internationalisation in the context of intersecting and contradictory aims and rationales.

There are multiple rationales and practices operating simultaneously in the context of the emphasis on internationalising HE. Breaking down the key discourses evident in strategic documents and interview transcripts, one cannot identify a document or transcript as purely neoliberal or liberal. Rather, the discursive orientations in fact appear to intersect in important ways. For that reason, we added a second part of the heuristic: the four interfaces of the main discursive orientations (neoliberal-liberal, neoliberal-critical, liberal-critical and all combined) (see Figure 2). The interfaces provide more nuance to the analysis. For example, in the neoliberal-liberal interface, the fusing of the two main orientations is seen in practices like accreditation, where the aim is to enhance the quality of the institution for partially economic benefit (developing the university brand, attracting more international students, receiving more research funding etc.) and for academic benefits. The neoliberal-critical interface would manifest, for example, as recruitment of students through grant schemesto increase student numbers from a certain country-that aim at widening participation and 
makes the university appear as more 'inclusive'. However, at the same time, this serves a marketing purpose by presenting a positive image for potential fee-paying students from that country. The liberal-critical interface would fuse the main orientations and recognize the barriers for participation but drive change more on a personal than systemic level. As an example of this would be providing temporary grant programs for disadvantaged domestic students that enable wider participation but does not alleviate the source of the disadvantage itself. Finally, the fourth interface is a combination of signifiers that appeal to all three main orientations. When analyzing the data, the interfaces help to show the potential shifts in discourses especially whereby the corporate imaginary overlaps with and even mediates the civic imaginary. 


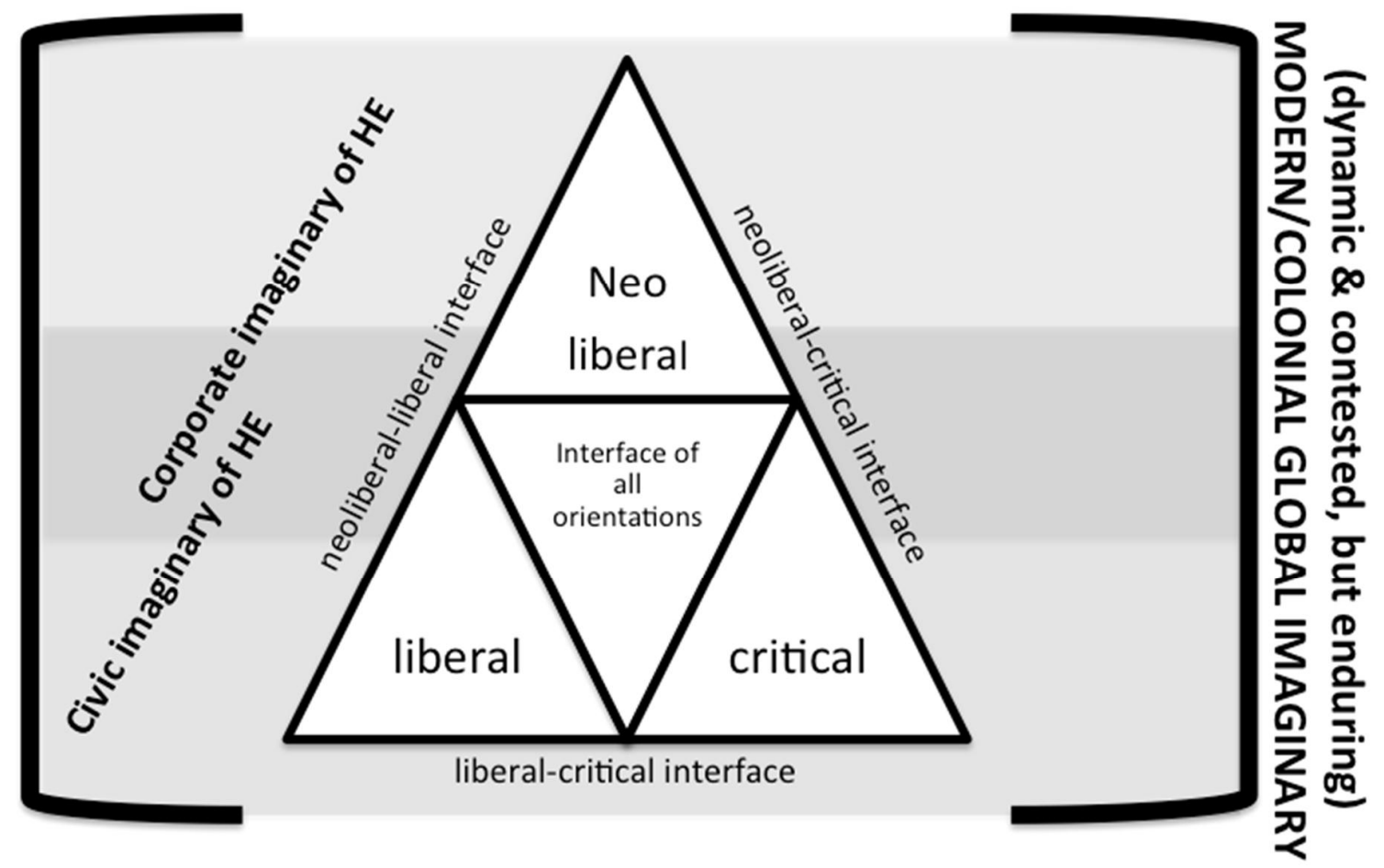

Figure 2. Corporate/civic discursive orientations of higher education (Andreotti et al., 2016:

8, republished under Creative Commons Attribution Licence 4.0).

Our use of the heuristic is first and foremost meant to facilitate discussion on the rationales of internationalisation of HE that also includes potential alternative approaches. In the data, all the orientations or their interfaces were not equal represented, especially the critical. The analysis of the strategy documents and interviews using the discursive orientations and the interfaces show the dominance of, firstly, the neoliberal and, secondly, the liberal orientations 
as well as the interface between them. The critical orientation was less evident in the data but in order to discuss the potential alternatives, through the heuristic, we can articulate what the orientation or its interfaces could contain. In our mappings of the findings (figures 3. and 4.), we also contributed to the heuristic by flushing out the 'arrows' or links from the interfaces to the three main discursive orientations to further map out the slight turns of discourse that intersect within rationales for internationalisation broadly and for increasing student numbers more specifically. Mappings as spatial visualisations of the data also make visible the spaces where discourses are missing. Following the idea of post-representational cartography (Kitchin et al., 2010) where maps are understood as processes rather than mirrors of the world, we have filled the empty spots with our own articulations based on the experiences in the larger project as well as research literature. Methodologically, a limitation of the mapping itself is that it is neither representative nor generalizable in that it represents themes and examples drawn from across diverse contexts and does not represent a quantitative representation of how often or how prevalent each example is. Still, while the critical is the least evident, the cartography allows us to articulate both the potential for that orientation to be part of and perhaps mediate these discussions and also for it to fall into interfaces with the other two in potentially unhelpful ways. 
Next, we will proceed to the analysis of our data. Both the strategy documents and the interviews are analysed and mapped separately and the findings are compared in the discussion part at the end of the paper where we consider possible ethical implications of promoting a more diverse international student population in policy and practice.

\section{Internationalisation strategies in university documents}

The university strategy documents showed a strong neoliberal orientation overall, and internationalisation is tied generally to a rationale of responding to the global market. For example, the University of Exeter in the UK focuses on the income generating potential of international recruitment (University of Exeter, 2013: 28), and the University of Oulu in Finland aims to double its 'competed international research funding' (University of Oulu, 2015:2).

There are also examples of the neoliberal-liberal interface in the documents, particularly in the rationale of reputation building that is tied to branding and marketing. University of Exeter focuses on building a "profile and brand [that is]... both clear and synonymous with quality' (University of Exeter, 2014: 29). The idea of academic rigor and reputation, tied to 
a liberal orientation, interfaces with a marketization rationale, a neoliberal orientation. For example, NUI Galway seeks to be 'regarded as a university of choice, relevance, and renown in the eyes of the world' (National University of Ireland, Galway, 2014: 1), University of Stirling also seeks to "be recognised as the destination of choice for students in the subject areas we offer' (University of Stirling, 2011: 16), and DeMontfort University in the UK aims to 'enhance [its] reputation for...world-leading research, teaching and global industry partnerships, attracting highest caliber students and staff' (DeMontfort University, 2011: 1). Örebro University in Sweden articulates an aim to 'consolidate its position on the international research arena' (Örebro University, 2013: 13). The neoliberal-liberal interface is also connected to honing a university's 'communications and...public image' at University of Helsinki (University of Helsinki, 2012: 8). While at the time of this study Finland had not yet introduced international student fees, there is a strong imperative to increase student numbers to heighten the profile of the university. For example, the University of Helsinki aims at systemic and active recruitment whereby 'the international admission procedure will be expedited' (University of Helsinki, 2012: 17). A theme across the university documents is a focus on developing and reinforcing opportunities of the two-tier degree structure created through the Bologna system as a recruitment channel (University of Helsinki, 2012: 17). It is difficult to distinguish between academic goals and financial ones as the imperative to raise 
the reputation of the university intersects with attracting international students and assumes a ready source of highly qualified individuals who will fit perceived gaps in the national labor market. While one could assume that higher academic quality and vigor could tie to knowledge sharing and generation-a liberal orientation the stronger discourse here appears to be branding and marketing - a neoliberal orientation.

The university documents also attend to the question of how to grow and sustain international student numbers. Growth in international student numbers is considered a 'key growth objective' (DeMontfort University, 2011: 25). Many documents mention the need for structures to support international students. Pastoral care is a strongly liberal orientation to supporting individual students and can interface with a critical orientation in promoting equity by understanding systemic barriers faced by certain groups of international studentsfor example, those who have specific dietary needs based on religion. Yet, supporting international students also interfaces with a neoliberal orientation as it is presented as key to maintaining a marketing edge through a strong reputation. For example, DeMontfort University (2011) sets an objective to go beyond simply increasing numbers through several strategies: a competitive fee price and package for support for international students; a focus on retention and post-qualification employment opportunities for international students; and 
the provision of a wide range of social and cultural support, living arrangements, and choice for international students. These can benefit both the students and the university and reflect a neoliberal-liberal interface as a neoliberal orientation of marketing again more strongly frames this rationale. The support of international students is directly tied to 'developing the international student "offer" so as to increase our market share of international students recruited' (DeMontfort University, 2011:26).

There are also examples of the liberal orientation in the concept of internationalisation of $\mathrm{HE}$ serving to change the world for the better, and this is tied strongly to valuing diversity. For example, Södertörn University has 'set its goal on making good use of the richness of experiences, languages and knowledge that exist amongst students and staff members at the university’ (Södertörn University 2011: 9). Their statement on internationalisation focuses strongly on the idea that bringing diverse people together is both the means and outcome of diversity:

The university shall be an international higher education institution, where education and research are distinguished by diversity, widened perspectives and an intercultural approach. In addition, ordinary activities at the university shall offer students, 
teachers and staff an international environment in which meetings between different cultures naturally occur. (Södertörn University, 2012: 1)

Similarly, DeMontfort University seeks to be an 'an international community where students and staff from diverse backgrounds and cultures learn from and enrich each other' (DeMontfort University, 2011: 5) and the University of Exeter recognizes that through internationalisation 'curriculum, research and culture are enriched by diversity' (University of Exeter, 2014: 27). Also, the University of Oulu recognizes that 'multiculturalism and globalisation are among the most important opportunities presented to it' (University of Oulu, 2015: 2).

There are hints at the critical interfaces in these documents. This is most strongly evident in the Strategic Plan document at NUI Galway: 'As a historic university situated in one of the world's economically privileged nations, we will endeavour to promote sustainable international development, human rights, and globally conscientious citizenship' (National University of Ireland, Galway, 2014: 5). The recognition of economic privilege suggests a critical orientation expressing a commitment to equity which is supported by the directive to 'offer scholarships and fee-structures that accommodate the globally diverse socioeconomic 
backgrounds of our potential students (National University of Ireland, Galway 2014: 5). The list of intentions includes promoting interdisciplinary academic programs to 'leverage' crossinstitutional activity and consistently delivering 'a compelling message about NUI Galway's promotion of ethical internationalisation' (National University of Ireland, Galway, 2014: 5). Here the neoliberal idea of marketing and leveraging the academic nature of the university's work-a neoliberal-liberal interface-intersects with a recognition of economic privilege on the part both of the institution and certain groups of students and the need to accommodate students from marginalized communities_-a critical interface.

A focus on strategic markets for international student recruitment and research partnerships reveals a strong overall neoliberal agenda when it comes to diversifying the international student population. The University of Stirling (2011) articulates a planned outcome: 'diversify the student population to achieve a greater proportion of different nationalities' (University of Stirling, 2011:22). Similarly, University of Exeter wants to 'grow the total of international fee-paying students' and 'continue to diversify by attracting more students from a wider range of countries than at present (University of Exeter, 2014: 5), noting an 'overrepresentation of Chinese students' and an 'over-representation of Chinese students in business' (University of Exeter, 2014: 11). Similarly, NUI Galway sets a target to increase 
the percentage of students from outside of Ireland and 'geographic spread of student population; EU/non-EU distribution of students' (National University of Ireland, Galway, 2014: 6). In Finland, the University of Oulu seeks to increase both student exchanges with European universities and exchange cooperation with 'strategic partners outside Europe' (University of Oulu, 2015: 6), a goal tied to increasing the numbers of Masters programs taught in a language other than Finnish or Swedish.

Given the strong neoliberal orientation to the drive to increase student numbers, overall, the push to diversify seems to reflect a marketization imperative. However, our heuristic enables us to consider how this imperative interfaces with other orientations. For example, there is a liberal-critical orientation evident in the idea of increasing access to HE. University of Exeter articulates a need to reach 'out to students of all backgrounds, to help them recognize the benefits of higher education and to encourage them to aspire to gain a place at university' (University of Exeter, 2014: 11). The University of Oulu 'seek[s] bilateral student exchange activities...in developing countries in particular' (University of Oulu, 2015: 5). And in its articulation of a commitment to 'ethical internationalisation', NUI Galway will 'offer scholarships and fee-structures that accommodate the globally diverse socioeconomic backgrounds of our potential students' (National University of Ireland, Galway, 2014: 5). At 
the same time, the documents reflect a desire for a range of international partners in established regions to boost reputation as well as partnerships with universities in countries that are future trading partners, or emerging economies. Most of the documents mention strategic regions that are the focus for recruitment and partnerships. China is a consistent focus (National University of Ireland, Galway, 2014; University of Exeter, 2014; University of Oulu, 2015) as is the US (National University of Ireland, Galway, 2014; University of Exeter, 2014).

The document analysis demonstrates both a dominating neoliberal orientation to internationalisation in HE generally and to the imperative to both increase and diversify the international student population. Using the heuristic, we have created a social cartographic mapping of the findings (see Figure 3). The location of the neoliberal orientation at the top of the triangle symbolizes that it is a dominant orientation; yet, we also can map both key themes emerging from the other two orientations and the interfaces between them. Using social cartography can be both a reflexive and iterative process. Drawing on the iterative aspect of social cartography, we have used italics in spaces on the heuristic where we did not find examples from the documents but can articulate what could be expressed from that orientation. 


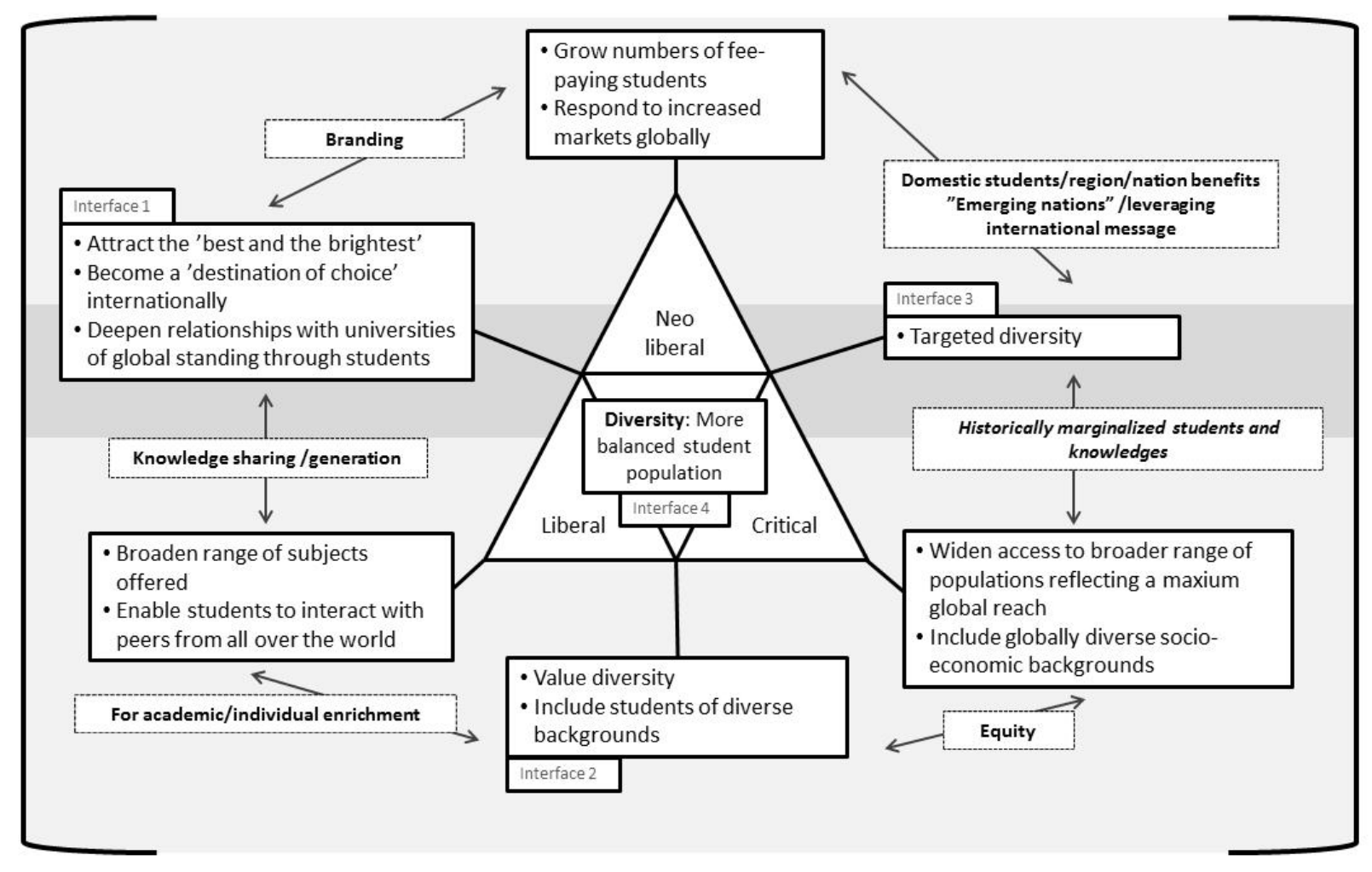

Figure 3. Social cartography of key themes emerging from the document analysis 


\section{Internationalisation strategies in the interview data}

Similarly to the strategy documents, the interviews portrayed most dominantly a mixture of neoliberal and liberal rationales in internationalisation. Critical rationales were rare in the interviews and when evident, mostly interfaced with the liberal orientation. However, unlike the strategy documents where neoliberal orientations seemed to be the most emphazised, the neoliberal-liberal interface in internationalisation was the most visible discursive orientation in the interviews. Similarly to the strategy documents, the justifications for the liberal rationales could be, in many occasions, traced back to the neoliberal rationales suggesting that the neoliberal orientation is strong in its framing of other orientations. Some interviewees made the connection more implicitly, while others were very much aware of the dominance of neoliberal rationales in internationalisation in the institutions. Although the rationales in the interviews were understandably varied, due to the range of national and international contexts across the different universities, the discourse of reputation building through internationalisation was strongly present in all interviews, similarly to the strategy documents. The anticipation was that interviews in UK and Ireland would be somewhat different from the Nordic countries due to the longer history with tuition fees and the lower government spending on HE but the economic aspects of internationalisation were still 
strongly present in all interviews, in one form or another. The biggest difference between the English-speaking and the Nordic countries had to do with the discourses on incoming mobilities. Whereas in Finland and Sweden both incoming and outgoing non-degree exchanges were always discussed with little attention on incoming degree mobility, in UK and Ireland, the interviewees rarely mentioned incoming non-degree mobilities but focused on outgoing domestic exchange students and incoming fee-paying degree students. This can be partly explained by the shorter history of tuition fees in the Nordic countries but also a more liberal approach to internationalisation, at least on the surface level. Still, the civic imaginary of the university was very strongly present in all interviews and emphasising the economic side of internationalisation was not necessarily seen as a comfortable subject. Perhaps, as a result, the liberal orientation was often used to 'soften' the message regarding the dominance of the economic driven rationales. As an example and related to the sense of unease between the economic rationales and a liberal sensibility related to the drive to increase student numbers through internationalisation, one interviewee noted that:

...using internationalisation to generate additional students and therefore additional income... is a very strong driver but also, of course, international students bring much 
more to the classroom, you know, [than] their fees, they bring international perspective they bring diversity, they bring globalisation. (D2)

International student recruitment was in roughly half of the interviews justified especially through the neoliberal-liberal interface as the increased flows of incoming degree or exchange students were a way to 'diversify the campus' and facilitate home internationalisation. Instead of a purely liberal rationale, this type of diversification can be seen as interfacing with the neoliberal as the aim is to develop the academic environment while at the same time creating a reputation as a more 'welcoming' or inclusive campus, and thereby to market international student recruitment. As a more liberal approach, international students were seen very important for the 'multiculturalisation' of the campus and the 'internationalisation' of the domestic staff and students. Bringing diverse people onto campus was seen as both the means and outcome of diversity in line with the strategy documents. It is noteworthy that only two UK and one Swedish interviewees included their existing multiethnic and multicultural students on campus in the diversification discourse which was centered around incoming international students. 
One of the key themes within the diversification of the campus discourse was the aim of internationalisation of the curriculum that involved, apart from the re-evaluating the actual curriculum and making it more 'globally relevant', changes in the attitudes of the domestic staff and students towards internationalisation. Seven interviewees noted that the domestic staff were not necessarily interested in engaging with internationalisation, and more specifically, with the incoming students, who were seen as additional work:

...we do work with internationalisation, we then are, of course, interested in this and we love to have more students going out and have more students coming in but lots of people work in the university with other things that are not directly involved in internationalisation processes. They are not always that interested in this issue and I think that is one of the most challenging aspects for us to reach out and convince colleagues, teachers, other staff that internationalisation is important. (H2)

Nevertheless, the teaching staff were in most interviews indicated as the main driver of internationalisation of the curriculum but the university-level support mechanisms to facilitate the process were not explicated clearly in the interviews. In a way, the situation is paradoxical; the teaching staff is perceived to be lacking in skills for intercultural education 
but are at the same time expected to 'internationalise' their teaching without being assisted in the process by their university. The internationalisation of the curriculum process could potentially include elements of the critical discursive orientation if it would be aimed at pluralising epistemologies and democratization of knowledges through incorporating indigenous and southern knowledges and pedagogies (Paraskeva, 2013; Baker, 2012). However, based on the interviews, the aims were more geared towards the neoliberal-liberal interface through the focus on quantitative and instrumental factors. In Finland and Sweden, the staff's skills in English and their willingness to teach in another language were questioned and partly blamed for the perceived lack of internationalised curriculum that was somewhat reduced to English-taught curriculum. Also, the internationalisation of the curriculum discourse focused mostly on increasing the numbers of English-taught courses and degrees to facilitate growth in student numbers. In the English-speaking countries, problems were more related to the attitudes of the staff and the lack of 'international examples' in their teaching. Across all countries, recruiting teaching staff abroad was seen as automatically contributing to the internationalisation of the curriculum. Interviews with especially the administrative staff, showed a more instrumental approach to the process of the internationalisation of the curriculum, where language of instruction, increased amount of English-taught content and a perceived international dimension of the teaching materials took 
precedence over the epistemic choices and pedagogic style in teaching. However, as internationalisation is largely a top-down process, these activity-oriented and instrumental approaches are the norm (De Wit, 2011).

Concerns over the engagement of domestic students in internationalisation were voiced as well. All interviewees emphasized the need to increase outward mobility of students in order to ensure their international competence and skills, and exchanges were also seen as a way to make the university more international through the diversification of the campus discourse. As two interviewees noted, the returning domestic students were perceived by the interviewees as being much more empathetic towards the international students through their personal experience. The home internationalisation activities were perceived to have similar effects. For example in the UK, internationalisation was seen by the interviewees as very much a part of the 'student experience', and because the amount of students taking part in an exchange or internship abroad was low, the universities were taking the most systematic approach to home internationalisation through special programs to ensure the international competencies for all students. In Finland and Sweden, probably due to higher outgoing mobility figures, home internationalisation was less emphasized than in UK and Ireland. Again, the liberal orientations in internationalisation interface with the neoliberal rationale 
of facilitation of student recruitment through building a more international and welcoming environment. While this was seen as important, the integration between domestic and international students was perceived as a problem:

...[We] need to support the interaction between the international students, and you know, the domestic students, for the lack of a better term, as so that there is, they are an integrated cohort, otherwise you are going to have two ghettos and that's not an international experience in the true sense... (C2)

The integration was not seen as occurring naturally and thus requiring supporting measures, namely the internationalisation of the curriculum and the related internationalisation at home. Across the interviews, sharing of experiences in the classes and different events was seen as a gateway to integration and creating a welcoming campus that would guarantee the 'international experience' for all students of the 'international university'. In the Englishspeaking universities, problems with integration were seen especially when there were too many international students in a classroom creating what is viewed as large 'monocultural' groups on campus. Interviewees mentioned the current need for diversification within diversification: 
You do want an international strategy which means, you know, drawing people from many different parts of the world. So diversification for us has become a counterbalance to the growth in volume that we've experienced in the recent years. So, we want growth but we want growth in a particular manner now. (E1)

As this interviewee's response indicates, a key challenge of internationalisation is to ensure no single ethnic background is overrepresented on campus as that is perceived as negative by teachers and students. Increasing student numbers was also discussed from the view-point of support services and international students, particularly degree students, were seen as requiring and/or deserving more supports, tailored to their needs, than the domestic students. The interface between liberal and neoliberal orientations is evident in how the perceived need for additional support is also used to justify the higher fees paid by the non-EEA students. Student support can also be examined through a critical discursive orientation when measures are taken to facilitate participation of disadvantaged students facing systemic barriers. Two UK interviewees discussed disadvantaged domestic students who would be given guidance and financial support in order to take part in exchange periods which can be understood through the liberal-critical framing of increasing equity and participation in 
internationalisation. Similarly, two interviewees also hinted at special grant programmes for students from 'emerging economies' that can either be seen as increasing participation (liberal-critical) or as supporting targeted recruitment from the same countries later on (neoliberal-critical). Although both cases address more equal participation, they cannot be viewed purely through the critical orientation that would require addressing, and changing, the systemic barriers causing the disadvantages in the first place (see for some of the complexities involved Salisbury et al. 2010; Marginson, 2012).

In the interviews, increasing the international student numbers was clearly connected to some form of income generation (for example, tuition fees in UK and Ireland, research monies through prestige in all countries and additional government funding in Finland) but strongly framed through the neoliberal-liberal interface. Many internationalisation activities like internationalisation of the curriculum and internationalisation at home could be seen through the liberal-neoliberal interface. On one hand, the purpose is to develop the academic environment and facilitate knowledge sharing and generation. On the other hand, the economic implications are a strong driver as well, through the increased student recruitment and leveraging of internationalisation for branding purposes. Like with the strategies, we have created a mapping of the interview findings (Figure 4). As there were no examples of 
the purely critical orientation in the interviews, we used italics to articulate what the rationales might potentially look like.

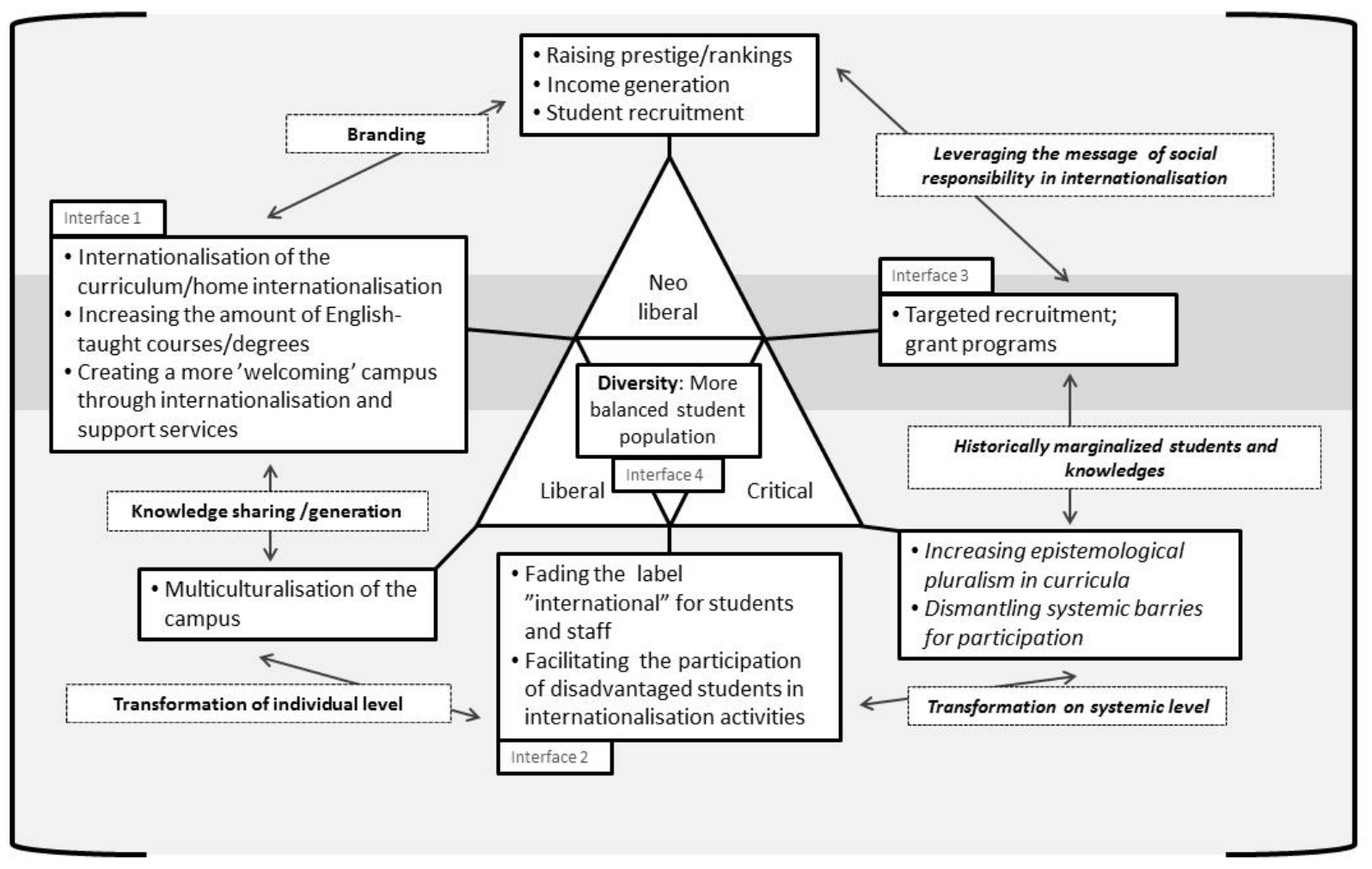

Figure 4. Social cartography of key themes emerging from the interview transcript analysis 


\section{Discussion}

In recent years, there has been rising attention towards reimagining internationalisation of HE (Knight, 2014; Britez \& Peters; 2010, Paraskeva, 2013) that attempts to divert the attention from the liberal/neoliberal binary to the values of both approaches and how they might interact in potentially unhelpful ways. Internationalisation is never a neutral process and the examination of the often invisible power relations are needed in order to imagine more ethical practices and to disrupt the 'business as usual approaches' (Tesar, 2016b: 594; Khoo, 2011; Baker, 2012). In this paper, we have contributed to the discussion by analysing the different discourses framing rationales in internationalisation in the international strategy documents and the interviews. By focusing on the topic of increasing international student numbers, we have attempted to open up the complex discursive terrain of internationalisation of HE where conflated and overlapping rationales have the potential to reproduce unethical practices. We have also taken part in the reimagining discussion through mapping discursive gaps and potential alternatives using social cartography. Our analysis of the strategy documents and interviews demonstrate a dominance of neoliberal and secondarily of liberal orientations, as well as the interface between them. Both the policies and interviews show an emphasis on increasing the amount of international students and the diversification of the 
campus. Although the economic rationales were the most dominant, the liberal and critical orientations and their interfaces could be found as well, showing how different discourses are conflated in the practice of internationalisation as well as on the strategy level. The neoliberal rationales are much more visible in the strategy documents as the interviewees tended to approach the different themes in internationalisation more through the liberal rationales. However, further probing into the topics showed that the discourses available to discuss the liberal rationales, like international student support and the benefits of a diverse campus, could be traced back to market rationales in the forms of increased student recruitment and global reputation. The interviewees reflected on the economic emphasis in internationalisation more or less explicitly, and the corporate imaginary was not really questioned which is in line with the hegemonic position of neoliberalism globally and the universities' role in the knowledge economy (Peters, 2012).

The discourses tied to a liberal orientation in the data emphasize the importance of diversity on campus that becomes a site of mutual learning benefitting the domestic and international students and staff alike. Processes to facilitate the diversity on campus include internationalisation of the curriculum as key to the overall quality of education and the integration, and provision of support services for international students. Although, the liberal 
rationales were often found to be framed through the neoliberal discursive orientations, the data included a few examples of intersections with the liberal-critical that dealt with increasing the access of disadvantaged students in HE and internationalisation activities. This interface shows a deeper recognition of injustices but when the liberal orientation is dominant, the focus is, for example, on special and temporary grant programs, instead of a more transformative approach which would address access and equity on a more permanent level as highlighted in the critical orientation.

Discourses representing the critical orientation to increase the international student numbers were the least represented in the document data and absent in the interview data. The critical examples in the document analysis included recognition of economic privilege and the subsequent need to increase the access of historically marginalized students. We attempted to fill the 'discursive gaps' in the interview data by articulating that the critical orientation could contain more emphasis than the other orientations on dismantling systemic barriers for access regarding domestic and international students. Also, in order to promote cognitive justice, there would be a commitment to epistemic pluralism in the contents of education offered to all students in HE. Examples of the critical interfacing with the neoliberal were found in the both sets of data and they were connected with targeted grant programs for 
students from specific 'emerging economies' that can widen participation of marginalized groups (like in the liberal-critical interface) but is connected to aspirations for further student recruitment in the same countries/areas. In this interface, where the neoliberal orientation is the strongest, the focus is more on leveraging the message of international social responsibility for economic purposes and branding. Leaning more towards the critical side, the interface would emphasise the inclusion of historically marginalized peoples, and the extent to which this focus on targeted diversity could promote systemic change or be mediated by a branding rationale is open for further research.

Overall, our data and analysis demonstrates that the internationalisation of HE is a complex discursive space that requires further examinations. While there is a dominance of neoliberal discursive orientations that often present a barrier to considering the ethical implications of, for example, selecting target markets for recruitment and/or supporting students as a means for further recruitment and marketing, the liberal and critical orientations represent possibilities to interrogate a neoliberal hegemony and the reproduction of unequal power relations. We hope that our use of the heuristic inspires reflexivity on the part of researchers and practitioners working in the context of internationalisation and promotes the formulation of key questions around the assumed benefits and ethics of internationalisation. 


\section{References:}

Abdi A and Shultz L (eds) (2008) Educating for Human Rights and Global Citizenship. New York: New York State University Press.

Andreotti V (2009) Engaging critically with 'objective' critical analysis: a situated response to Openshaw and Rata. International Studies in Sociology of Education 19(3): 217 -227.

Andreotti V, Jefferess D, Pashby K, et al. (2009) Difference and conflict in global citizenship in higher education in Canada. International Journal of Development Education and Global Learning 2(3): 5-24.

Andreotti V, Stein S, Pashby K, et al. (2016) Social cartographies as performative devices in research on higher education. Higher Education Research \& Development 35(1): 8499.

Baker M (2012) Modernity/Coloniality and Eurocentric Education: towards a postOccidental self-understanding of the present. Policy Futures in Education 10(1): 4-22.

Britez R and Peters MA (2010) Internationalization and the cosmopolitical University. Policy Futures in Education 8(2): 201-216. 
DeMontfort University (2011) Strategic plan 2011-2015. Available at:

http://www.dmu.ac.uk/documents/about-dmu-documents/quality-management-andpolicy/governance/dmu-strategic-plan.pdf (accessed 15 September 2016).

De Wit H (2011) Internationalization of Higher Education: Nine Misconceptions. International Higher Education 64: 6-7.

Dower N (2003) An Introduction to Global Citizenship. Edinburgh: Edinburgh University Press.

European Commission (2013) European higher education in the world. Available at: http://eur-lex.europa.eu/legalcontent/EN/TXT/PDF/?uri=CELEX:52013DC0499\&from=EN (accessed 15 September 2016).

Fairclough N (2003) Analysing discourse: Textual analysis for social research. London: Routledge.

Fairclough N and Wodak R (2008) The Bologna Process and the knowledge-based economy: a critical discourse analysis approach. In: Jessop B, Fairclough N and Wodak $\mathrm{R}$ (eds) Education and the Knowledge-Based Economy in Europe. Rotterdam: Sense Publishers, pp.109-125. 
Kemp N and Lawton W (2013) A Strategic Analysis of the Scottish Higher Education Sector's Distinctive Assets. Edinburgh: British Council Scotland.

Khoo SM (2011) Ethical globalisation or privileged internationalisation? Exploring global citizenship and internationalisation in Irish and Canadian universities. Globalisation, Societies and Education 9(3-4): 337-353.

Khoo SM (2012) Re-routing the postcolonial university: educating for citizenship in managed times. In Andreotti V and de Souza L (eds) Postcolonial Perspectives on Global Citizenship Education. New York: Routledge, pp.200-220.

Kitchin R, Perkins C and Dodge M (2009) Thinking about maps. In: Dodge M, Kitchin R and Perkins C (eds) Rethinking maps: New frontiers in cartographic theory. London: Routledge, pp. 1-25.

Knight J (2014) Is internationalisation of higher education having an identity crisis? In: Maldonado-Maldonado A and Bassett RM (eds) The Forefront of International Higher Education: A Festschrift in Honor of Philip G. Altbach. Dordrecht: Springer, pp.75-87. Lomer S (2014) Economic Objects: how policy discourse in the United Kingdom represents international students. Policy Futures in Education 12(2): 273-285.

Marginson S (2012) Including the other: regulation of the human rights of mobile students in a nation-bound world. Higher Education 63(4): 497-512. 
National University of Ireland, Galway (2012) NUI Galway strategic Plan 2009-2014 Interim Report. Available at:

http://www.nuigalway.ie/president/documents/strategic_planinterimreportjune2012.pdf (accessed 15 September 2016).

National University of Ireland, Galway, International Sub-Group (2014) International SubGroup, Strategic Plan 2015-2020 Internationalisation. June 13 [internal document].

Nokkala T (2007) Constructing the Ideal University - The Internationalisation of Higher Education in the Competitive Knowledge Society. Tampere: Tampere University Press.

Örebro University (2013) Vision 2016. Available at: https://www.oru.se/globalassets/orusv/om-universitetet/vision/orebro_universitet_vision2016.pdf (accessed 15 September 2016).

Paraskeva J (2013) Whose Internationalization? Journal of the American Association for the Advancement of Curriculum Studies 9(1): 1-5.

Pashby K and Andreotti V (2016) Ethical internationalisation in higher education: Interfaces with international development and sustainability. Environmental Education Research 22(6): 771-787.

Paulston R (1999) Mapping Comparative Education after Postmodernity. Comparative Education Review 43(4): 438-463. 
Peters M (2012) Neoliberalism, Education and the Crisis of Western Capitalism. Policy Futures in Education 10(2): 134-141.

Rizvi F and Lingard B (2010) Globalizing Education Policy. New York: Routledge.

Rhoads R and Szelényi K (2011) Global Citizenship and the University: Advancing Social Life and Relations in an Interdependent World. Stanford: Stanford University Press.

Schatz M (2016) Engines without fuel? - Empirical findings on Finnish higher education institutions as education exporters. Policy Futures in Education 14(3): 392-408.

Seeber M, Cattaneo M, Huisman J and Paleari S (2016) Why do higher education institutions internationalize? An investigation of the multilevel determinants of internationalization rationales. Higher Education. Epub ahead of print 29 January 2016. DOI: $10.1007 / \mathrm{s} 10734-015-9971-x$.

Södertörn University (2011) Research and Education Strategy for Södertörn University 2012-2014. [Forsknings- och utbildningsstrategi för Södertörns högskola 2012-2014] Available at: https://www.sh.se/p3/ext/res.nsf/vRes/om_sodertorn_1313672101388_forsknings_och_u tbildningsstrategi_2012_2014_folder_pdf/\$File/Forsknings_och\%20_utbildningsstrategi _2012-2014_folder.pdf (accessed 19 September 2016). 
Södertörn University (2012) Internationalisation Policy. Governing Board Reg. no. 1910/40/2012. November 15 [internally distributed document].

Salisbury MH, Paulsen MB and Pascarella ET (2010) Why do All the Study Abroad Students Look Alike? Applying an Integrated Student Choice Model to Explore Differences in the Factors that Influence White and Minority Students' Intent to Study Abroad. Research in Higher Education 52(2): 123-150.

Slaughter S and Rhoades G (2004) Academic Capitalism and the New Economy: Markets, State, and Higher Education. Baltimore: Johns Hopkins University Press.

Stein S (2017) The Persistent Challenges of Addressing Epistemic Dominance in Higher Education: Considering the Case of Curriculum Internationalization. Comparative Education Review 61(S1): S25-S50.

Taylor S (2004) Researching educational policy and change in 'new times': Using critical discourse analysis. Journal of Education Policy 19(4): 433-451.

Tesar M (2016a) Policy and philosophy in the contemporary educational landscape. Policy Futures in Education 14(3): 311-313.

Tesar M (2016b) On ethics, policy and the philosophy of education. Policy Futures in Education 14(6): 593-596. 
Tolofari S (2009) Teething Problems of Market Entry: the Swedish tuition fees dilemma. Policy Futures in Education 7(1): 102-111.

University of Exeter (2013) International Exeter Report 2012-2013. University of Exeter. University of Exeter (2014) 2015: Our Vision, Our Strategy. Available at: http://www.exeter.ac.uk/media/universityofexeter/webteam/shared/contentimages/strate gicplan/Strategic_Plan_2015.pdf (accessed 19 September 2016)

University of Helsinki (2012) The best for the world: Strategic plan for the University of Helsinki 2013-2016. University of Helsinki: Unigrafia.

University of Oulu (2012) University of Oulu strategy for 2012-2015. Available at:

http://www.oulu.fi/ladattavat/vuosikertomukset/OY-vuosikertomus-2012-en.pdf (accessed 19 September 2016)

University of Oulu (2015) International University of Oulu: International Action Programme and Division of Labour 2012-2015. Internal document.

University of Stirling (2011) Strategic plan 2011-2016: Education founded on innovation and excellence. Available at:

http://www.stir.ac.uk/media/autoimport/data/assets/pdffile/0003/31836/StrategicPlan.pdf (accessed 19 September 2016) 
Wood LA and Kroger RO (2000) Doing Discourse Analysis: Methods for Studying Action in Talk and Text. London: Sage Publications Inc. 